Research Article

\title{
Sustainable housing using confined masonry buildings
}

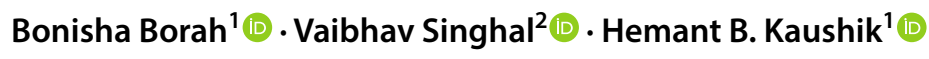

(c) Springer Nature Switzerland AG 2019

\begin{abstract}
Much of India is prone to substantial earthquakes, and vulnerability associated with both unreinforced masonry (URM) and improperly built reinforced concrete (RC) frame constructions has been unmasked by past earthquakes. URM structures present a severe hazard in earthquake-prone regions. And non-engineered RC structures can lead to devastating consequences. Housing for families in the economically weaker sector and the lower-income group is undoubtedly challenging to such events. Regardless of residing in a city or village, everyone desires a house with masonry walls and $\mathrm{RC}$ roof, just like the buildings in larger urban areas. Confined masonry (CM) construction, which is a popular building system in many countries, can fulfil this need of society. Though CM building started informally, the seismic performance is found to be really well in several destructive earthquakes. This type of construction combines the advantages of URM and RC structures and does not need sophistication required in RC construction. In this paper, the seismic response of URM, infilled RC frame and CM buildings is compared using past seismic performance and literature. It is concluded that confined masonry is a better alternative for sustainable housing in seismic-prone regions of India.
\end{abstract}

Keywords Unreinforced masonry · Reinforced concrete · Confined masonry · Seismic response

\section{Introduction}

In recent years, earthquakes occurring in India and other countries have unveiled many weaknesses associated with both unreinforced masonry (URM) and reinforced concrete (RC) frame construction. Both URM buildings and non-engineered RC frame buildings continue to be the major cause of human and economic losses during past earthquakes as observed during Bhuj (2001), Kashmir (2005), Sikkim (2011) and Nepal (2015) earthquakes. Confined masonry (CM) has emerged as an improved masonry structural system, where the unreinforced masonry walls are confined with nominally reinforced concrete tieelements (tie-columns and tie-beams) at the perimeter and other salient locations. Because of these small tieelements, the ductility of the structure under lateral load improves compared to the URM structure, which translates into better seismic performance. Though a finished
CM building looks like an RC frame building with infill walls, CM building does not need sophistication required in RC construction [1]. Here, the confining elements are not designed to act as load-bearing elements as in case of RC frame buildings with masonry infill; however, these are provided to tie together the walls, floors and roofs as well as to strengthen walls with openings. To study the economic aspect, Marques and Lourenço [2] estimated the costs associated with the construction of dwellings with RC, URM and CM typologies. Increase of $33 \%$ in the total cost was observed for the CM structure when compared to the URM structure. However, it allows a total cost reduction of $16 \%$ when compared to the RC structure. Mediumrise $\mathrm{CM}$ building had its first formal application in India in the form of a large-scale project involving the construction of $36 \mathrm{CM}$ buildings in the new campus of IIT Gandhinagar, Gujarat. Preliminary cost estimates indicated that adoption of CM technology resulted in a cost saving of $10-15 \%$

$\bowtie$ Bonisha Borah, bonisha@iitg.ac.in; $\varangle$ Hemant B. Kaushik, hemantbk@iitg.ac.in; Vaibhav Singhal, singhal@iitp.ac.in | 'Department of Civil Engineering, IIT Guwahati, Guwahati, Assam 781039, India. ${ }^{2}$ Department of Civil and Environmental Engineering, IIT Patna, Patna, Bihar 801106, India.

SN Applied Sciences (2019) 1:983 | https://doi.org/10.1007/s42452-019-1020-4

Received: 23 February 2019 / Accepted: 31 July 2019 / Published online: 5 August 2019 
over alternative $\mathrm{RC}$ frame construction [3]. The cost savings were mainly due to a smaller amount of concrete and steel because of smaller member sizes in CM buildings compared to RC frame buildings. Therefore, the CM structure combines the advantages of URM and RC structure, and the structure provides an economic advantage utilizing the masonry strength in the main load-bearing element. The past seismic performance of CM structure in comparison with other types is described in the next section.

\section{Past seismic performance}

The first reported use of $\mathrm{CM}$ construction was in the reconstruction of buildings destroyed by the 1908 Messina, Italy, earthquake of magnitude 7.2. After that, its practice started in Chile and Colombia in the 1930s and is currently widely used for housing construction, from lowrise (one-to-two storey) dwellings to multistorey (up to six storeys high) apartment buildings in several countries of high seismic risk [4]. CM structure has been subjected to many devastating earthquakes. Table 1 includes some countries where $\mathrm{CM}$ buildings have been used for housing construction and the history of remarkable earthquake experienced by them [5-17]. As mentioned in the past literature, the overall performance of the $\mathrm{CM}$ building in these earthquakes was very satisfactory. For example, in the earthquake performance report of 1939 Chile earthquake, 1999 Tehuacan earthquake, 2003 Tecomán earthquake and 2007 Pisco earthquake, CM structures showed

Table 1 CM building performance during past notable earthquakes

\begin{tabular}{llll}
\hline Country & Year & Earthquake location & Magnitude \\
\hline Chile & 1939 & Chillán & 7.8 \\
& 1985 & Llolleo & 7.8 \\
Mexico & 2010 & Coast of Maule & 8.8 \\
& 1985 & Guerrero-Michoacán & 8.0 \\
& 1999 & Tehuacan & 6.5 \\
Peru & 2003 & Tecomán & 7.6 \\
& 1970 & Chimbote & 7.8 \\
Colombia & 1983 & Popayan & 8.0 \\
& 1999 & El Quindio & 5.5 \\
Iran & 1990 & Manjil & 6.2 \\
& 2003 & Bam & 7.6 \\
El Salvador & 2001 & Offshore El Salvador & 6.6 \\
China & 1976 & Tangshan & 8.7 \\
Indonesia & 2004 & Northern Sumatra & 9.3 \\
& 2005 & Northern Sumatra & 8.7 \\
& 2007 & Bengkulu & 8.4 \\
Haiti & 2010 & Port-au-Prince & 7.0 \\
\hline
\end{tabular}

SN Applied Sciences

A SPRINGER NATURE journal far better performance than URM structure. Majority of CM buildings remained undamaged while the adjacent URM building (especially adobe construction) damaged severely or collapsed in these earthquakes. Also, in 1985 Guerrero-Michoacán earthquake, CM buildings showed better performance than even infilled RC frame buildings. Several reports of the past earthquakes have identified the out-of-plane collapse of URM and infilled RC frame wall as one of the predominant modes of failure. In the infilled RC frames due to construction difficulties, loose fitting of masonry beneath the concrete beam is quite common, which resulted in the out-of-plane collapse of these panels during the past earthquakes. However, a superior integration between the masonry and adjacent RC tieelements is naturally developed in CM walls because of the construction sequences. As the concrete is cast after the masonry wall, a good bond is developed between the wall and surrounding frame in CM building. Therefore, in these earthquakes, CM buildings were less vulnerable in the out-of-plane direction compared to URM or infilled RC frame buildings.

In general, because of the main concept, i.e. load-bearing masonry wall tied by small RC elements, CM structures showed excellent resistance to seismic events occurred in worldwide. A few CM buildings suffered severe damage, especially high-rise buildings but most low- and mediumrise dwellings did not experience any damage. The damage in CM buildings was found to be mainly due to the omission of tie-columns, discontinuity in tie-beams, poor diaphragm connections and inappropriate structural configuration. Therefore, if it is properly constructed, it can sustain earthquake effects without collapse. As a result, the $\mathrm{CM}$ structure has attracted considerable interest in the research field. Studies have been carried out to understand the behaviour of the $\mathrm{CM}$ building system in order to transform it into a proper engineered construction. In the next section, the behaviour of the CM structure under experimental study is discussed.

\section{Review of past literature}

Seismic behaviour of CM structure has been a subject of experimental studies from many years. Past experimental studies have contributed to the comprehensive understanding of the seismic behaviour of CM walls in terms of their damage pattern and failure modes. From the investigation of experimental test studies and past earthquake damage reports, the general failure modes of $\mathrm{CM}$ structures can be broadly categorized into in-plane failures, out-of-plane failures, diaphragm failures, connection failures and non-structural failures as shown in Fig. 1 [18]. Among these, the in-plane performance of $C M$ walls has 


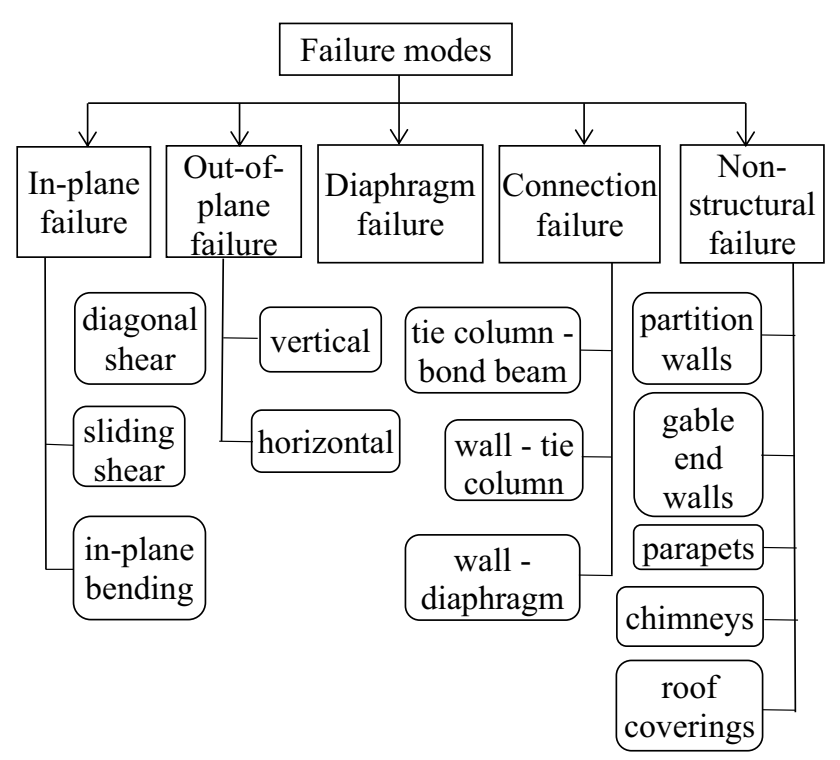

Fig. 1 Different failure modes of CM structure

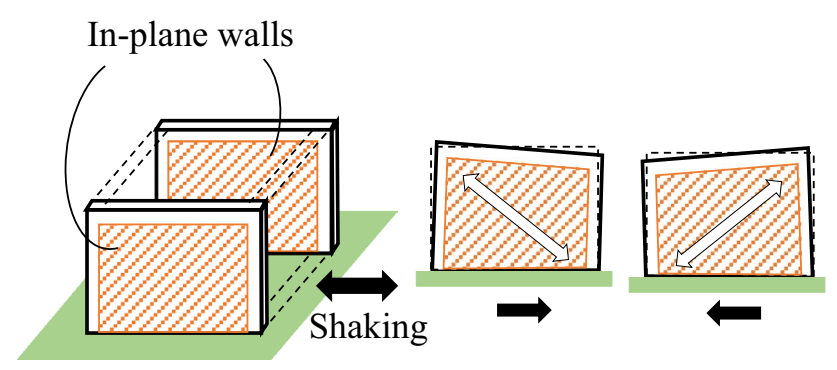

Fig. 2 CM wall subjected to in-plane loading

attracted considerable interest in the seismic research, as it is the primary load path for transferring lateral seismic forces to the foundation.

The summary of experimental studies conducted to understand the in-plane behaviour (Fig. 2) of CM walls in the past three decades is presented by Meli et al. [1]. It was observed that initially in a CM wall, the masonry panel resists the effect of lateral earthquake loads while the confining elements do not play a significant role (Fig. 3). Once the cracking takes place in masonry units or mortar joint, the panel becomes less effective in transferring the forces (Point A). If the lateral force continues to increase, the masonry panel typically begins to lose strength, and at this stage, the vertical reinforcement in tie-columns becomes engaged in resisting tensile and compressive stresses. Thus, even if the lateral loads on the wall exceed its capacity, because of tie-elements, the walls will stay together and continue to deform or stretch until the lateral loads lessen. In this way, the wall got significantly higher strength and considerably higher deformation capacity

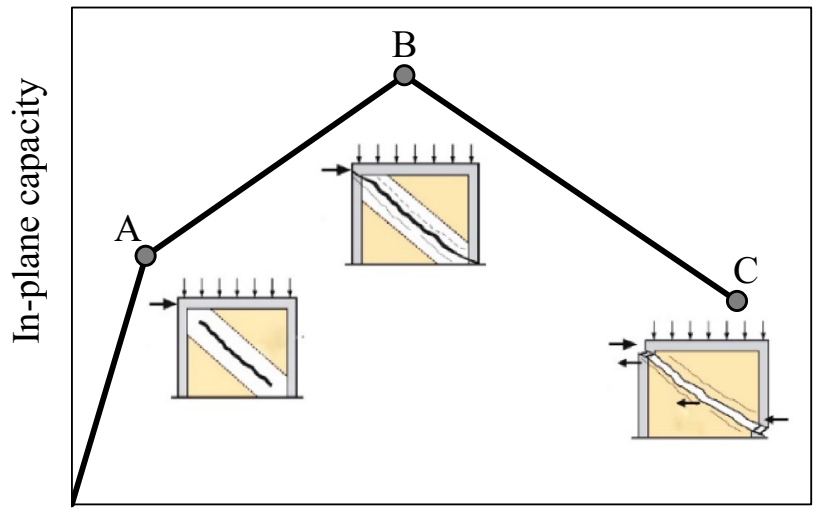

Displacement

Fig. 3 Idealized in-plane load-deformation envelope curve for CM wall [1]

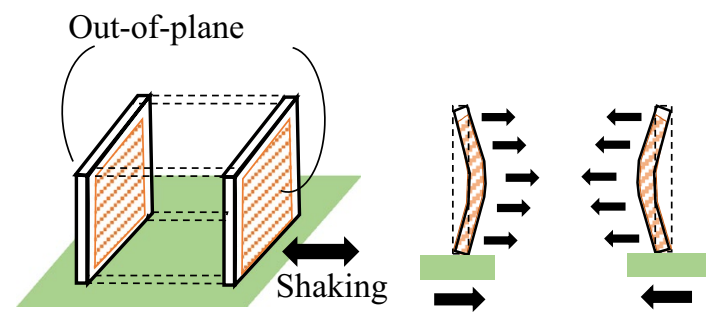

Fig. 4 CM wall subjected to out-of-plane loading

than URM walls and is prevented from collapse (Point B). These additional deformations cause further damage in the masonry and tie-columns. In many cases, ultimate failure occurs when the tie-columns completely fail in shear by the extension of diagonal shear failure of the panel (Point $\mathrm{C}$ ). Meli et al. also concluded that the maximum inplane resistance of $C M$ wall could be considered as the sum of the shear resistance provided by the plain masonry wall and the tie-columns. Further, the load-deformation behaviour depends on various factors, such as wall aspect ratio, material strength, type of wall-to-tie-column interface, detailing of tie-columns, wall openings and overburden pressure. [19-27].

During lateral loading, masonry walls may be subjected to out-of-plane lateral loading and vertical compression due to self-weight and overburden loads (Fig. 4). Out-ofplane lateral loading creates bending and shear stresses in the wall, and because of the low tensile strength of masonry, cracks may appear in walls leading to possible collapse by overturning. Overturning or out-of-plane failure mode is very common in URM and infilled RC frame structure. In case of URM structure, walls are constructed without any reinforcement, and in case of an infilled RC frame structure, walls are constructed inside stiff 
RC frames. However, in CM structure, the walls are constructed with flexible small RC confining elements around their perimeter and a superior integration between the masonry and adjacent RC elements is naturally developed due to the different construction sequences. As the masonry panels are tightly attached with the RC frame elements in case of CM structure, it exerts thrust on the beams and columns and forms effective arching mechanism [1]. Therefore, CM walls, in general, did not experience out-of-plane collapses in comparison with URM and infilled RC frames during past earthquakes. Several guidelines on CM emphasize on providing toothing or dowels at the wall-to-tie-column interface for satisfactory out-ofplane performance $[1,28,29]$. Very few experimental studies have been carried out on the out-of-plane behaviour of CM walls [29-34]. Several factors, such as, wall aspect ratio (height/length ratio), slenderness ratio (height/thickness ratio), type of floor diaphragm (rigid or flexible diaphragm), support conditions, stiffness of the surrounding $\mathrm{RC}$ frame, material characteristics, overburden pressure, etc., affect the out-of-plane capacity of wall [30-44].

The improvement in the in-plane performance of CM walls in comparison with URM and infilled RC frame walls was confirmed by different researchers [25, 45-47]. Yoshimura and Kikuchi [45] tested nine different specimens to compare the behaviour of CM wall with unreinforced masonry wall without any confining column and with infilled RC ductile moment-resisting frame having the same cross-sectional details as that of the CM specimen. As the $\mathrm{CM}$ wall specimen showed higher strength and ductility than the unreinforced masonry and infilled $\mathrm{RC}$ frame specimens, it was concluded that CM construction is the excellent structural system. Tomazevic and Klemenc [25] tested three specimens of confined and plain masonry walls with height-to-length ratio equal to 1.5, made at 1:5 scale, under the application of constant vertical load and programmed pattern of cyclically acting horizontal displacements. From their study, it was observed that by confining the wall with RC tie-columns, lateral resistance of a URM wall is improved by more than 1.5 times and deformation capacity by almost five times in addition to enhancing the energy dissipation capacity by six to seven times as shown in Fig. 5a. Yoshimura et al. [46] tested different types of unreinforced and confined concrete hollow block masonry wall specimens (2D and 3D specimens, walls with or without reinforcing bars or $U$-shaped connecting bars) under repeated lateral force (lateral load application point considered was at a height of 0.67 and 1.1 times the height of the wall measured from the top of the foundation beam), and constant axial stress (0.48 MPa and 0.84 MPa). From the study, it was concluded that the seismic performance of $C M$ wall is better than the conventional URM system. The CM walls with U-shaped
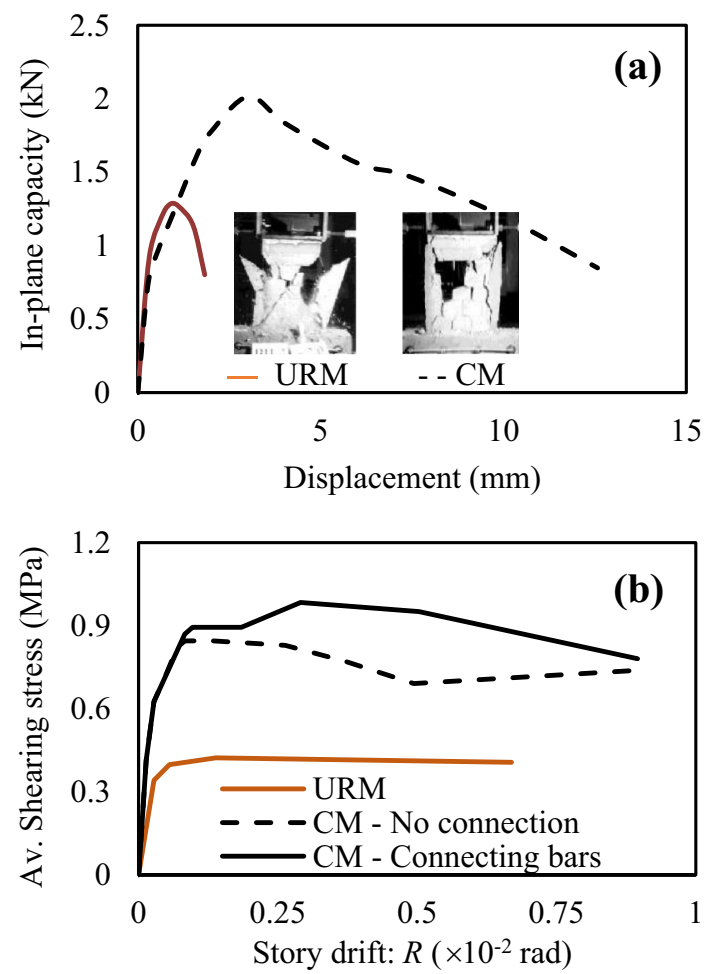

Fig. 5 Comparison of the in-plane response of CM and URM walls tested by: a Tomazevic and Klemenc [25], b Yoshimura et al. [46]

connectors and horizontal wall reinforcements developed moderately higher ultimate lateral strength with the increase in axial load and showed better ductility as compared to the URM wall specimens. Figure $5 \mathrm{~b}$ shows the shearing stress-versus-storey drift plot for 2D URM and $\mathrm{CM}$ wall specimens without wall horizontal reinforcement under axial stress of $0.48 \mathrm{MPa}$ and lateral load at the lower application point. As shown in the figure, $\mathrm{CM}$ specimen with $U$-shaped connecting bar improved the performance in terms of lateral load-carrying capacity and ductility. Goveia and Lourenço [47] tested nine URM (four with unfilled vertical joints, three with filled vertical joints and two with light bed joint reinforcement) and seven confined block masonry walls (two with unfilled vertical joints, three with unfilled vertical joints and light bed joint reinforcement and two with unfilled vertical joints and light bed joint reinforcement anchored to the confining elements), made at 1:2 scale, for constant vertical and horizontal cyclic load. From their study, it was observed that by confining the wall with RC tie-elements, the lateral capacity of standard URM wall is improved by 1.17 times and deformation capacity by 1.43 times.

Tu et al. [30] conducted shaking table tests on two fullscale single-storey structures to investigate the out-ofplane behaviour of CM walls of different thicknesses. The out-of-plane performance of these confined walls was also 
compared with infilled RC frames. The test results suggest that $\mathrm{CM}$ walls can sustain significant out-of-plane loads. The composite action between the wall and confining frames prevented the masonry panels from falling out of the frame and helped to reduce the influence of inertia forces caused by their self-weight. On the contrary, infill panels separated from the boundary frame and collapsed due to the out-of-plane inertia forces.

Practically, a seismic event can cause a masonry panel to experience both in-plane and out-of-plane loads simultaneously. The in-plane force causes damage to the wall by forming diagonal cracking, shear sliding or bending depending on the geometry of the wall. The in-plane damage of the wall affects the arching mechanism and reduces the out-of-plane capacity of the wall. Hence, the combined effect of in-plane and out-of-plane forces aggravates the extent of the damage. Singhal et al. $[22,23]$ tested halfscaled CM wall specimens with the different connections at the wall-to-tie-column interface (Fig. 6) and considered the successive applications of out-of-plane and in-plane loading. The seismic performance of $\mathrm{CM}$ wall in comparison with that of a typical infilled RC frame wall was also studied. It was observed that the CM walls with or without toothing exhibited improved in-plane and out-of-plane responses in comparison with the infilled RC frame wall, as shown in Figs. 7 and 8, respectively. The increased density of toothing caused significant improvement in post-peak behaviour under in-plane loads (Fig. 7). However, it did not have significant effect on out-of-plane behaviour up to the moderate level of damage (1.0\% drift) (Fig. 8). At higher in-plane drift, CM walls with toothing were more effective in controlling the OOP displacements than with no toothing. Under lateral loads, CM walls acted as shear walls, and due to the composite action between the wall and the tie-column, the out-of-plane failure was delayed, and the wall could safely sustain large in-plane drifts up to $1.75 \%$. However, the RC frame with infill masonry showed a separation of the wall panel at its interface with the framing element at in-plane drifts as low as $0.5 \%$, which led
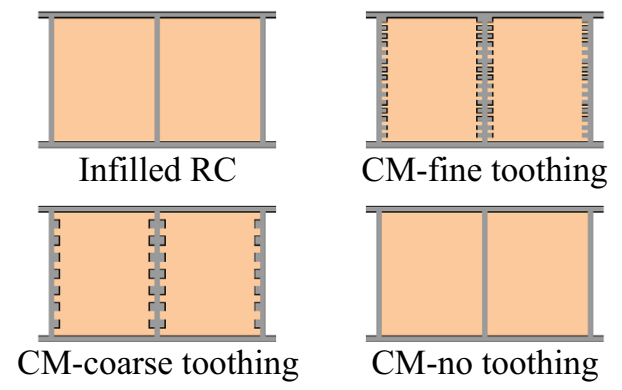

Fig. 6 Wall specimens prepared for the experimental investigation $[22,23]$

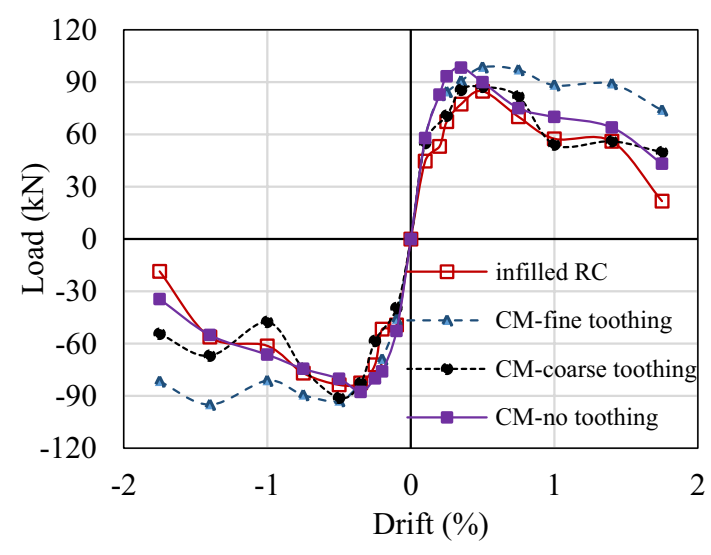

Fig. 7 Comparison of seismic response of infilled RC frame and CM walls $[22,23]$

to excessive out-of-plane deflection and increased risk of dislodgement from the frame.

\section{Conclusion}

In this paper, seismic performance of CM building in comparison with URM and RC frame building with infill walls is examined. From the study, it is clear that low-rise CM structure exhibits better in-plane and out-of-plane resistance in comparison with URM and infilled RC frame structures under any seismic event. URM structures provide very less lateral strength in comparison with CM structures, and because of the brittle behaviour, they have no reserved strength after cracking. Again to construct a proper RC frame building with infill walls requires technical skills and finances. Much of India is prone to substantial earthquakes

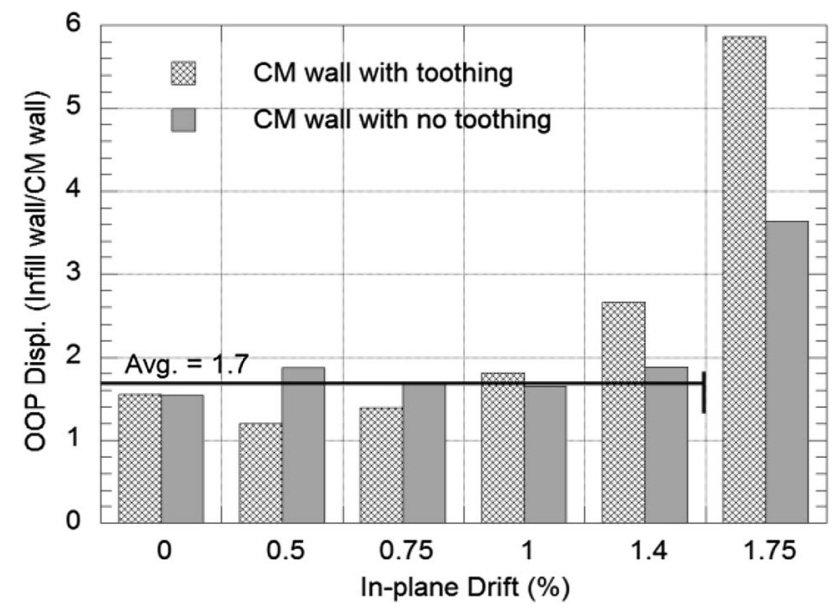

Fig. 8 Normalized out-of-plane displacement of infill wall with respect to CM walls at different in-plane drift (damage) levels [22, 23] 
and construction of earthquake-resistant housing for families in the economically weaker sector, and the lowerincome group is undoubtedly challenging. Confined masonry can be a useful construction technology because this practice does not require new or advanced construction skills or equipment. Same materials are used which are available in the country, that is, concrete, masonry and steel. It only requires nominal care in design and construction and yet performs very well in earthquakes. Therefore, confined masonry is a better alternative for sustainable housing in seismic-prone regions of India.

Funding This research is supported by a Grant from the Science and Engineering Research Board, Government of India (Grant No. $\mathrm{ECR} / 2018 / 000489$ ).

\section{Compliance with ethical standards}

Conflict of interest The authors declare that they have no conflict of interest.

\section{References}

1. Meli R, Brzev S, Astroza M, Boen T, Crisafulli F, Dai J, Farsi M, Hart T, Mebarki A, Moghadam AS, Quinn D (2011) Seismic design guide for low-rise confined masonry buildings. Earthquake Engineering Research Institute and International Association for Earthquake Engineering, Oakland. www.confi nedmasonry.org

2. Marques R, Lourenço PB (2014) Unreinforced and confined masonry buildings in seismic regions: validation of macroelement models and cost analysis. Eng Struct 64:52-67

3. Jain SK, Basu D, Ghosh I, Rai DC, Brzev S, Bhargava LK (2014) Application of confined masonry in a major project in India. In: Proceedings of the 10th national conference on earthquake engineering. Earthquake Engineering Research Institute, Anchorage

4. Brzev S (2008) Earthquake-resistant confined masonry construction. National Information Center for Earthquake Engineering, Kanpur

5. Moroni MO, Astroza M, Acevedo C (2004) Performance and seismic vulnerability of masonry housing types used in Chile. J Perform Constr Facil ASCE 18(3):173-179

6. Brzev S, Astroza M, Moroni O (2010) Performance of confined masonry buildings in the February 27, 2010 Chile earthquake. Earthquake Engineering Research Institute, Oakland

7. Schultz AE (1994) Performance of masonry structures during extreme lateral loading events. Masonry in the Americas, $\mathrm{ACl}$ Publication SP-147, American Concrete Institute, Detroit, pp 21-55

8. Jimenez Jl, Villarreal Jl, Centeno MR, Gonzalez BG, Correa JJ, Acevedo CR, Salazar IS (1999) Tehuacan, Mexico, earthquake of June 15, 1999. Seismol Res Lett 70(6):698-704

9. Alcocer SM, Klingner RE (2006) The Tecomán, México earthquake, January 21, 2003: an EERI and SMIS learning from earthquakes reconnaissance report. Earthquake Engineering Research Institute, Oakland
10. Gallegos H (1994) Masonry in Peru. Masonry in the Americas, ACI Publication SP-147, American Concrete Institute, Detroit, pp 307-331

11. Asfura A, Flores P (2000) El Quindio, Colombia earthquake, January 25, 1999: Reconnaissance report. An EERI learning from earthquakes project. Earthquake Engineering Research Institute, Oakland

12. Hashemi BH, Alemi F, Ashtiany G (2003) Confined brick masonry building with concrete tie-columns and beams. Iran, Report 27, World Housing Encyclopedia, Earthquake Engineering Research Institute, Oakland

13. Yang W, Jian Z (1988) Functions of tied concrete columns in brick walls. In: Proceedings of the 9th world conference on earthquake engineering, Tokyo, vol 6, pp 139-144

14. Bilek S, Satake K, Sieh K (2007) Introduction to the special issue on the 2004 Sumatra-Andaman earthquake and the Indian Ocean tsunami. Bull Seismol Soc Am 97(1A):S1-S5

15. Meisl CS, Safaie S, Elwood KJ, Gupta R, Kowsari R (2006) Housing reconstruction in Northern Sumatra after the December 2004 Great Sumatra earthquake and tsunami. Special Issue on the Great Sumatra Earthquakes and Indian Ocean Tsunamis of 26 December 2004 and 28 March 2005. Earthq Spectra 22(S3):S777-S802

16. EERI (1999) The Tehuacan, Mexico, earthquake of June 15, 1999. EERI Special Earthquake Report. Newsletter. Earthquake Engineering Research Institute, Oakland

17. EERI (2001) Preliminary observations on the El Salvador earthquakes of January 13 and February 13, 2003. EERI Special Earthquake Report. Newsletter. Earthquake Engineering Research Institute, Oakland

18. Matthews T, Riahi Z, Centeno J, Charlet A, Garcia H, Hoffman C, Safaie S, Elwood KJ (2008) Evaluation of confined masonry guidelines for earthquake-resistant housing. Confined Masonry Network, Earthquake Engineering Research Institute, Oakland

19. Riahi Z, Elwood KJ, Alcocer SM (2009) Backbone model for confined masonry walls for performance-based seismic design. J Struct Eng 135(6):644-654

20. Kuroki M, Kikuchi K, Nonaka H (2010) Experimental study on reinforcing methods for window openings in confined masonry walls. In: Proceeding of the 35th conference on our world in concrete and structures. Cl-Premier PTE LTD, Singapore

21. Gavilán Pérez JJ, Flores LE, Alcocer SM (2015) An experimental study of confined masonry walls with varying aspect ratios. Earthq Spectra 31(2):945-968

22. Singhal V, Rai DC (2014) Seismic behavior of confined masonry walls when subjected to in-plane and out-of-plane loading. 10th US National Conference on Earthquake Engineering, Paper no. 675, Anchorage

23. Singhal V, Rai DC (2016) In-plane and out-of-plane behavior of confined masonry walls for various toothing and openings details and prediction of their strength and stiffness. Earthq Eng Struct Dyn 45(15):2551-2569

24. Singhal V, Rai DC (2018) Behavior of confined masonry walls with openings under in-plane and out-of-plane loads. Earthq Spectra 34(2):817-841

25. Tomaževič M, Klemenc I (1997) Seismic behavior of confined masonry walls. Earthq Eng Struct Dyn 26(10):1059-1071

26. Chourasia A, Bhattacharyya SK, Bhargava PK, Bhandari NM (2013) Influential aspects on seismic performance of confined masonry construction. Nat Sci 5(08):56

27. Borah B, Singhal V, Kaushik HB (2019) Assessment of important parameters for seismic analysis and design of confined masonry buildings. National Conference on Advances in Structural Technologies, Paper no. 138, Silchar

28. Schacher T (2009) Confined masonry for one and two storey buildings in low-tech environments-a guidebook for 
technicians and artisans. National Information Centre of Earthquake Engineering, Kanpur

29. Schacher T, Hart T (2015) Construction guide for low-rise confined masonry buildings. Confined Masonry Network, New York

30. Tu YH, Chuang TH, Liu PM, Yang YS (2010) Out-of-plane shaking table tests on unreinforced masonry panels in RC frames. Eng Struct 32(12):3925-3935

31. Varela-Rivera JL, Navarrete-Macias D, Fernandez-Baqueiro LE, Moreno El (2011) Out-of-plane behaviour of confined masonry walls. Eng Struct 33(5):1734-1741

32. Varela-Rivera J, Moreno-Herrera J, Lopez-Gutierrez I, FernandezBaqueiro L (2012) Out-of-plane strength of confined masonry walls. J Struct Eng 138(11):1331-1341

33. Moreno-Herrera J, Varela-Rivera J, Fernandez-Baqueiro L (2014) Bidirectional strut method: out-of-plane strength of confined masonry walls. Can J Civ Eng 41(12):1029-1035

34. Moreno-Herrera J, Varela-Rivera J, Fernandez-Baqueiro L (2015) Out-of-plane design procedure for confined masonry walls. J Struct Eng 142(2):04015126

35. Navarrete-Macias D, Varela-Rivera J, Fernandez-Baqueiro L (2016) Out-of-plane behavior of confined masonry walls subjected to concentrated loads (one-way bending). Earthq Spectra 32(4):2317-2335

36. Drysdale RG, Essawy AS (1988) Out-of-plane bending of concrete block walls. J Struct Eng 114(1):121-133

37. Dawe JL, Seah CK (1989) Out-of-plane resistance of concrete masonry infilled panels. Can J Civ Eng 16(6):854-864

38. Al-Chaar G, Angel R, Abrams DP (1994) Dynamic testing of unreinforced brick masonry infills. In: Structures congress XII: proceedings of papers presented at the structures congress, Atlanta, GA. American Society of Civil Engineers, Reston, pp 791-796

39. Bashandy T, Rubiano NR, Klingner RE (1995) Evaluation and analytical verification of infilled frame test data. Report 95-1, Department of Civil Engineering, University of Texas, Austin
40. Abrams DP, Angel R, Uzarski J (1996) Out-of-plane strength of unreinforced masonry infill panels. Earthq Spectra 12(4):825-844

41. Henderson RC, Fricke KE, Jones WD, Beavers JE, Bennett RM (2003) Summary of a large-and small-scale unreinforced masonry infill test program. J Struct Eng 129(12):1667-1675

42. Griffith MC, Lam NTK, Wilson JL, Doherty K (2004) Experimental investigation of unreinforced brick masonry walls in flexure. $J$ Struct Eng 130(3):423-432

43. Komaraneni S, Rai DC, Singhal V (2011) Seismic behavior of framed masonry panels with prior damage when subjected to out-of-plane loading. Earthq Spectra 27(4):1077-1103

44. Derakhshan H, Griffith MC, Ingham JM (2013) Airbag testing of multi-leaf unreinforced masonry walls subjected to one-way bending. Eng Struct 57:512-522

45. Yoshimura K, Kikuchi K (1995) Experimental study on seismic behaviour of masonry walls confined by R/C frames. In: Proceeding of the Pacific conference on earthquake engineering, Australia, vol 3, pp 97-106

46. Yoshimura K, Kikuchi K, Kuroki M, Nonaka H, Kim KT, Wangdi R, Oshikata A (2004) Experimental study for developing higher seismic performance of brick masonry walls. In: Proceedings of the 13th world conference on earthquake engineering, Vancouver, Paper no. 1597

47. Gouveia JP, Lourenço PB (2007) Masonry shear walls subjected to cyclic loading: influence of confinement and horizontal reinforcement. In: 10th North American masonry conference, St. Louis

Publisher's Note Springer Nature remains neutral with regard to jurisdictional claims in published maps and institutional affiliations. 